\title{
CRIMINAL LAW: DEMISE OF "STATUS"- "ACT" DISTINCTION IN SYMPTOMATIC CRIMES OF NARCOTIC ADDICTION
}

In Watson v. United States ${ }^{1}$ the Court of Appeals for the District of Columbia Circuit held that Title II of the Narcotic Addict Rehabilitation Act of $1966^{2}$ was unconstitutional insofar as it excluded individuals who had two pre-1966 felony convictions from rehabilitation eligibility. More importantly, the court suggested a course for subsequent constitutional challenge of statutes punishing the use or possession of narcotics by non-trafficking addicts. Albert Watson, a drug addict, was charged with violations of sections 4704(a) of title $26^{3}$ and 174 of title $21^{4}$ which make possession of unstamped narcotics prima facie evidence of unlawful dealing. Although his defense was based primarily upon traditional insanity grounds, Watson moved for dismissal after the conclusion of the evidence on the ground that the eighth amendment prohibited the punishment of a narcotics addict for possession of narcotics. Watson was found guilty, and the judge, considering him ineligible for disposition under the Narcotic Addict Rehabilitation Act of 1966 because of his two prior felony convictions, sentenced him to the mandatory minimum of ten years imprisonment. ${ }^{5}$ On appeal, a panel of the court of appeals held that the ten-year mandatory minimum sentence was in violation of the eighth amendment as cruel and

1. No. 21,186 (D.C. Cir. July 15, 1970).

2. 18 U.S.C. $\S \S 4251-55$ (Supp. IV, 1969). The Act is designed to provide medical rehabilitative treatment for convicted narcotics addicts in lieu of traditional criminal disposition and sentencing.

3. INT. ReV. CODE of 1954, § 4704(a) provides, in part:

It shall be unlawful for any person to purchase, sell, dispense, or distribute narcotic drugs except in the original stamped package or from the original stamped package; and the absence of appropriate taxpaid stamps . . . shall be prima facie evidence of a violation of this subsection. . . .

4. Narcotic Control Act of 1956, 21 U.S.C. $\S 174$ (1964). This section prohibits the importation of unlawful narcotic drugs into the United States and the receipt, concealment, purchase, or sale of such drugs. It further provides:

Whenever on trial for a violation of this section the defendant is shown to have or to have had possession of the narcotie drug, sucb possession shall be deemed sufficient evidenee to authorize conviction unless the defendant explains the possession to the satisfaction of the jury.

5. No. 21,186 at 7-8. 
unusual punishment, vacated the sentence, and requested briefs regarding the final disposition of the case. ${ }^{b}$ An amicus curiae brief contended that the criminal sanctions of narcotics laws should not apply to non-trafficking addicts, that the exclusion classification of the 1966 Narcotic Addict Rehabilitation Act based upon two prior felony convictions was a denial of equal protection as applied to appellant, and that the court should recognize a new and separate defense of involuntariness for narcotics addicts. ${ }^{7}$ The court of appeals, sitting en banc, found that the Act, as applied to the appellant, was a violation of equal protection, vacated the sentence, and remanded the case to the district judge for resentencing and consideration under Title II of the Narcotic Addict Rehabilitation Act of 1966.

In the past decade courts have frequently considered the relationship between the eighth amendment's prohibition of cruel and unusual punishment and the imposition of criminal penalties upon narcotics addicts for crimes relating to their status as addicts. In 1962 the Supreme Court in Robinson v. California ${ }^{8}$ reversed the conviction of a narcotics addict under a California statute which made the "status" of addiction a crime. The Court, specifically recognizing narcotics addiction as a disease, ${ }^{10}$ reasoned that the eighth amendment's prohibition against cruel and unusual punishment prevented the incareeration of an addict for his "status" of addiction as distinguished from punishment for the "acts" of trafficking in or possessing narcotics." In two 1966 courts of appeals cases ${ }^{12}$ applying Robinson to the closely related issue of public drunkenness, the criminal convictions of chronic alcoholics for public drunkenness were reversed; in dicta,.the courts noted the logical inconsistency of proscribing punishment for a disease, yet allowing punishment for the symptoms of that disease. ${ }^{13}$. Most state and federal courts have, however, refused to extend Robinson and have maintained the

\footnotetext{
6. Id. at 10.
}

7. For a discussion of traditional notions of involuntariness, see Gillars v. United States, 182 F.2d 962 (D.C. Cir. 1950).

8. 370 U.S. 660 (1962).

9. Cal. Health \& Safety Code § 11721 (West 1964).

10. 370 U.S. at 667 n.8. The Court noted: "thirty-seven years ago this Court recognized that persons addicted to narcotics are 'diseased and proper subjects for [medical] treatment." Id. (citations omitted).

11. Id. at 664 .

12. Easter v. District of Columbia, 361 F.2d 50 (D.C. Cir. 1966); Driver v. Hinnant, 356 F.2d 761 (4th Cir. 1966).

13. 361 F.2d at $54-55 ; 356$ F.2d at 764-65. 
position that, although an addict may not be held criminally liable for his "status," he may be prosecuted for his "acts" of possession and use. ${ }^{14}$ These decisions were buttressed by the Supreme Court in Powell v. Texas ${ }^{15}$ where a Texas statute ${ }^{16}$ punishing public intoxication was held constitutional as applied to a chronic alcoholic. The Court, distinguishing Robinson, reasoned that the statute did not punish the "status" of alcoholism but rather punished the anti-social "act" of public drunkenness. ${ }^{17}$ Courts applying criminal sanctions to symptomatic crimes of narocitcs addiction since Powell have relied heavily upon the Court's distinction between "status" and "act" to support their refusal to extend Robinson..$^{18}$ Most commentators, however, have chided the courts for their refusal to expand Robinson and have criticized a judicial reasoning which forbids the punishment of a person as an addict while permitting a similar sanction for the possession and use of narcotics..$^{19}$

Claims that the compulsion of narocitcs addiction should provide exoneration from criminal sanction have also been rejected by the courts. In Bailey $v$. United States ${ }^{20}$ the court, in rejecting an addict's argument that his habit compelled him to obtain contraband drugs and that, therefore, he should not be held criminally responsible, declared that no court has accepted the narcotics-compulsion theory alone as grounds for acquittal. ${ }^{21}$ The Court of Appeals for the Second Circuit has held that the present state of medical knowledge does not allow a judicial conclusion that narcotics addicts should avoid criminal liability because of their addiction. ${ }^{22}$ While the compulsion

14. See, : :g., Bailey v. United States, 386 F.2d 1 (5th Cir. 1967); Freeman v. United States, 357 F.2d 606 (2d Cir. 1966); Hutcherson v. United States, 345 F.2d 964 (D.C. Cir. 1965); United States ex rel. Swanson v. Reincke, 344 F.2d 260 (2d Cir. 1965); People v. King, 29 111. 2d 150, 193 N.E.2d 790 (1963); State ex rel. Blouin v. Walker, 244 La. 699, 154 So. 2 d 368 (1963);

State v. Reed, 34 N.J. 554, 170 A.2d 419 (196I).

15. 392 U.S. 514 (1968).

16. TEXAS PEN. Code art. 477 (1952).

17. 392 U.S. at 532.

18. See, e.g., Rangel v. State. 444 S.W.2d 924 (Tex. Crim. App. 1969).

19. See generally Cuomo, Mens Rea and Status Criminality, 40 S. CAL. L. Rev. 463 (1967); McMorris, Can We Punish for the Acts of Addiction, 54 A.B.A.J. 1081 (1968); Neibel, Implications of Robinson v. California, 1 Houston L. Rev. 1 (1963); Survey, Constitutionality of Conviction Under Narcotics Statute, 41 WASH. L. REV. 533 (1966); Note, Robinson v. California-Legal Implications of Narcotics Addiction as a Disease Rather than a Crime, 57 Nw. U.L. REv. 618 (1962). But see McKevitt, The "Untouchable" Acts of Addiction, 55 A.B.A.J. 454 (1969).

20. 386 F.2d 1 (5th Cir. 1967).

21. Id. at 4.

22. United States v. Freeman, 357 F.2d 606, 625 (2d Cir. 1966). 
of narcotics addiction is not recognized alone as an affirmative defense, many courts do allow evidence of narcotics addiction to support a traditional insanity defense. ${ }^{23}$ Commentators generally believe that narcotics addiction slould be more than "some" evidence of criminal incapacity. Citing numerous medical authorities, Professor Bowman contends that narcotics addiction is generally an indication of a mental defect wlich, wlile alone not satisfying traditional insanity criteria, does, when combined with the pliarmacological compulsion of drug addiction, require a modified test of criminal responsibility for narcotics addicts. ${ }^{24}$

Faced witl the body of precedent refusing to extend Robinson and the general judicial refusal to treat narcotics addiction as an affirmative defense, the Court of Appeals for the District of Columbia was confronted by the Watson case. In discussing appellant's arguments that Congress either did not intend to punisl the nontrafficking addict for possession of narcotics for personal consumption or, if it did, the statute would be unconstitutional under Robinson, the court explained that the incomplete record, caused by Watson's failure to raise these issues until after the conclusion of evidence, precluded adjudication of such an important question of statutory construction with constitutional overtones. ${ }^{25}$ As to Watson's criminal responsibility contentions, the court found that the trial judge had properly submitted the conflicting testimony of the expert witnesses on the issue of insanity to the jury and refused to formulate a new test of criminal responsibility for narcotics addicts. ${ }^{26}$ However, the court did suggest that a future defendant miglit challenge the applicability of those portions of the federal narcotics laws that impose criminal sanctions for the possession and use of narcotics to a non-trafficking addict while alternatively asserting a Robinson defense. ${ }^{27}$ The defendant, the court stated, would have the burden of going forward witl evidence that he was a non-trafficking addict in possession of narcotics solely for his own use; once the

23. E.g., Bailey v. United States, 386 F.2d 1, 4 (Sth Cir. 1967); United States v. Freeman, 357 F2d 606, 625 (2d Cir. 1966); People v. Zapata, 220 Cal. App. 2d 903, 908, 34 Cal. Rptr. 171, 174 (1963), appeal dismissed, 377 U.S. 406 (1964).

24. Bowman, Narcotic Addiction and Criminal Responsibility Under Durham, 53 Geo. L.J. 1017, 1043 (1965). See also authorities cited in note 19 supra.

25. No. 21,186 at 21 .

26. Id. at 15-16.

27. Id. at 21-22. The defendant would raise these issues by a motion to dismiss under FED. R. CRIM. P. 120. 
defendant had produced such evidence, the prosecution would have the burden of proving the contrary beyond a reasonable doubt as in a traditional insanity situation. ${ }^{28}$ Finally, the court held that the two-prior felony exclusion provision of Title Il of the Narcotic Addict Rehabilitation Act of 1966 as applied to appellant was unconstitutional under the equal protection provision of the fifth amendment. ${ }^{29}$ The court noted that the second exclusionary provision of Title II excludes individuals convicted of unlawful dealing in narcotic drugs from eligibility for disposition under the Act unless the court determines that the dealing was primarily to enable the defendant to obtain a narcotic drug that he requires for his own consumption, while the fourth exclusionary clause excludes an individual who has been convicted of any felony on two or more prior occasions. These sections created an unconstitutional distinction between addicts who did not have two convictions at the time of the 1966 Act and addicts who did have two convictions at that time: the addict with two or more pre-1966 convictions could have been convicted upon a mere showing of possession of narcotics absent the provision for the determination of whether the defendant's possession was for the primary purpose of personal consumption. Thus, in view of the avowed purpose of the Narcotic Addict Rehabilitation Act of 1966 to punish criminal dealing in narcotics and to rehabilitate addicts, the court concluded that the distinction between the two classes of addicts was unconstitutionally discriminatory. ${ }^{30}$ Chief Judge Bazelon concurred with the court's decision but urged that Watson's appeal was an appropriate case for an examination of the relationship between drug addiction and criminal responsibility. Alternatively, Bazelon reasoned that the appellant had adequately challenged the reach and constitutionality of the statutes under which he was convicted..$^{31}$ Judge Robb, dissenting, felt that the majority had correctly perceived that the Act benefitted some addicts while denying treatment to others but did not agree that the distinction violated the equal protection clause. Arguing that reform may proceed on a stepby-step basis beginning with the phase of the problem that seems most acute, Judge Robb contended that the legislature's approach to the

28. Id. at 22 .

29. Id. at 29 .

30. Id.

31. Id. at 32 . 
problem was reasonable and that therefore the Act did not deny equal protection to those addicts with two pre-1966 felony convictions. ${ }^{32}$

Both the majority and concurring opinions in Watson suggest that at least one court is prepared to change the judicial treatment of narcotics addicts. ${ }^{33}$ The decision indicates that successful arguments for modification of the law as related to narcotics addiction can be found in an extension of Robinson's interpretation of the eighth amendment, narrow statutory interpretation, and evolving notions of criminal responsibility and insanity. While the Supreme Court in Robinson stated that its decision would not preclude punishment for possession of or dealing in narcotics, ${ }^{34}$ it will not be an easy task for the Court to explain why an addict may not be punished for addiction, yet may be punished for his symptomatic possession of narcotics for use. ${ }^{35}$ However, the difficulties in delineating the "symptoms" of the disease of narcotics addiction may lead courts to avoid the constitutional issue and dispose of challenges to the convictions of narcotics addicts for personal possession and use on statutory grounds. Although the statutory argument in Watson was concerned solely with the federal narcotics statutes, similar state statutes ${ }^{36}$ may also be attacked on the theory that the statutes are not applicable to non-trafficking addicts. The final basis for change suggested by Watson, a revision of judicial notions of criminal responsibility and insanity, may be the most desirable innovation since it would support further consideration of other psycho-pharmacological factors which compulsively produce criminal behavior but which cannot be accommodated by traditional doctrines of insanity or involuntariness. ${ }^{37}$ Because narcotics addiction in most cases is symptomatic of an underlying mental illness ${ }^{38}$ and because the compulsion of narcotics addiction eventually subjugates all aspects of the addict's life to the goal of obtaining a steady supply of drugs, ${ }^{39}$ a

32. Id. at $43-44$.

33. If Robinson retains validity, "it must also mean in all logic that (1) Congress either did not intend to expose the non-trafficking addict possessor to criminal punishment, or (2) its effort to do so is as unavailing constitutionally as that of the California legislature." Id. at 19.

34. 370 U.S. at 664.

35. No. 21,186 at 23 .

36. See, e.g., LA. Rev. Stat. § 40:962A (1950); Wisc. Stat. ANN. § 161.02(3) (1951).

37. For the prevailing insanity doctrine in the District of Columbia, see MeDonald v. United States, 312 F.2d 847 (D.C. Cir. 1962).

38. See Bowman, supra note 24 , at 1031 .

39. Id. at 1038 . 
"new" test of criminal responsibility for the drug addict would not appear to be a radical departure from traditional insanity defenses. If this new test is combined with hospital commitment powers in the judge, ${ }^{40}$ the resulting treatment of the narcotics addict as a patient rather than as a criminal may well lead to a decrease in the recidivist rate of addicts and may finally make twentieth century judicial notions of involuntariness consistent with twentieth century scientific and psychological theory.

40. See, e.g., CAL. Wel. \& INST'NS CODE § 6357 (1966). 